\title{
ПРОБЛЕМИ ЗАСТОСУВАННЯ ПОЛІГРАФОЛОГІЧНИХ ДОСЛІДЖЕНЬ
}

УДК: 159.9.075

\section{Мул Сергій Анатолійович}

Доктор психологічних наук, доцент Національного педагогічного університету ім. М. П. Драгоманова, м. Київ (Украӥна)

\begin{abstract}
Анотація. В статті досліджується проблема неоднозначності застосування поліграфа, наводяться приклади впровадження поліграфів. Автором виділяються окремі статичні душевні переживання, тобто психологічні стани, які відчуває особистість під час проведення поліграфологічних досліджень такі, як брехня, обман, настрій, радість, тривога, страх, хвилювання, спокій. Наголошується на наявності необхідної умови уміння спеціаліста-поліграфолога вивчити психологічний стан досліджуваного. Звертається увага на те, що досвідчений поліграфолог здатен ще до початку проведення дослідження скласти психологічний образ досліджуваного, через протиріччя поглядів на доказову базу здобуту поліграфологічним дослідженням автор рекомендує застосовувати комбінований спосіб отримання правдивої інформачії. Приділяється увага підготовиі спеціаліста-поліграфолога. Він повинен мати знання з філософії, психологї, права, анатомії, математики, фізики. Вбачається подальща перспектива досліджень у створенні системи поглядів психологї на проблеми прогнозування недостатньої чесності через припущення майбутньої делінквентної поведінки через показники особистісної девіантності, як сочіапатична особистість та психопатична девіація.
\end{abstract}

Ключові слова: поліграф, психофізіологічне дослідження, психологічний стан, детектор, дослідження, тести, оцінка, висновки, цінності, вибір.

\section{Постановка проблеми у загальному} вигляді. Сьогодні у світі поліграфологічні дослідження впроваджено більш як у 70 країнах світу, а США має досвід застосування поліграфа близько 100 років, де щороку при влаштуванні на роботу в урядові структури проходять перевірку близько 70000 кандидатів. Переважний спектр застосування психо- фізіологічних досліджень це правоохоронні органи країн-лідерів. В Європі активне застосування поліграфа розпочалось на початку 90-х років: у Швеції, Данії, Нідерландах, Швейцарії. На початку 2000-х років використання зазначеної технології було впроваджено в Республіці Білорусь, де за результатами проведених досліджень правоохоронцями 
розкрито понад 4,5 тисячі надскладних кримінальних злочинів. Незважаючи на досить активне застосування зазначених психофізіологічних технологій, в Австралії та Австрії такі дослідження заборонені, а в окремих країнах, навпаки, застосування таких технологій закріплено законами (США, Литва, Молдова).

Вивчений досвід та теоретичні дослідження проблеми застосування поліграфологічних досліджень вказує на наявність відмінних поглядів вчених на застосування поліграфа. 3 одного боку науковці стверджують, що такі технології не варті уваги, через наявність факторів об'єктивізму. Інші навпаки, наводять факти його ефективного використання та результати, переконують, що це новий метод здобуття прихованої інформації, викриття злочинів тощо. У цьому напрямку дослідження проводили Барко В. І., Біленчук П. Д., Гончаренко В. Г., Мотлях О. І., Рибальченко О. М., Усіков І. П. Морозова Т. Р., Поповічев С. В., Шаповалов В. А., Гордон Н., Сміт Н., Шафер Д., Штеллер М. та інші.

Необхідність досліджень проблем поліграфологічних технологій зумовлена, насамперед, активним розвитком і впровадженням в психології сучасних технічних розробок та технологій. Перші прилади були великі, громіздкі та потребували значних коштів на їх розробку, сьогодні ж поліграф це ноутбук, датчики, крісло. Не дивлячись на удосконалені технічні особливості пристрою, залишаються активними під час досліджень по суті впливу на психічне життя особистості емоції, брехня, обман, почуття, образи.

В Україні поліграф почав застосовуватися в середині 2000-х років і сьогодні ми $є$ свідками його активного впровадження в суспільно-правоохоронне життя країни.

Застосування поліграфа в Україні здійснюється на таких засадах:

- основне знаряддя діагностики, що дозволяє отримати більш конкретну інформацію про кандидата на посаду, використовується метод психофізіологічного тестування, тобто тестування за допомогою поліграфів;

- використання поліграфа законом прямо не забороняється;

- $\quad$ ліцензія на придбання зазначеного обладнання і використання не потрібна;

- проведення поліграфічних перевірок не суперечить чинному законодавству України і не порушує його, воно має на меті передусім захист прав фізичних і юридичних осіб у галузі трудових відносин;

- $\quad$ не порушуються конституційні права громадян, оскільки перевірки здійснюються лише $з$ їх письмової згоди.

Використання поліграфа в Україні здійснюється на підставі Конституції України, законодавства про працю та інших нормативноправових актів. Так у статті 28 Конституції України наголошується: «Жодна людина без їі вільної згоди не може бути піддана медичним, науковим чи іншим дослідам». Його викорис- 
тання підпадає під формулювання «інші досліди». У ст. 32 Конституції України закріплено: «Не допускається збирання, зберігання, використання та поширення конфіденційної інформації про особу без її згоди». [8]

Тобто наявність письмової згоди досліджуваного на застосування поліграфа $є$ обов'язковою.

На сьогодні в Україні поліграф застосовують в МВС, МО, ГУР МО, СЗР, СБУ, Держприкордонслужбі, Національній гвардії та інших органах та структурах.

Інформація, отримана в результаті проведення психофізіологічної експертизи з використанням поліграфа, є непрямим доказом, що підтверджує лише суб'єктивну значущість конкретних стимулів, які можуть вказувати на наявність приховуваної інформації про обставини злочину або на щирість відповідей при опитуванні. Сили доказів результати використання поліграфа набувають тільки у рамках призначеної судової експертизи.

На наш погляд неоднозначність суджень дослідників про ефективність застосування поліграфологічних досліджень, тобто, не зовсім об'єктивний вплив результатів дослідження на людську долю, психічне життя особистості потребують опрацювання загальнодержавних стандартів, правил застосування психофізіологічних технологій та визначення сфер їх використання. До цих норм ми відносимо, як юридичну, так і психологічну складовi.
Метою статті с дослідження сучасного стану психофізіологічних досліджень, окремих психологічних станів людини під час використання поліграфа.

\section{Теоретико-методологічна основа дос-} лідження. Проблема дослідження психічних станів неодноразово досліджувалась сучасною психологією.

У 1875 році італійський фізіолог Анжело Моссо опублікував роботу з розвитку інструментальної детекції брехні. Дослідник довів, що залежно від величини емоційної напруги змінюється низка фізіологічних показників. Зокрема, кров'яний тиск у судинах людини й частота пульсу змінюються залежно від коливань емоційного стану обстежуваної особи [11].

Розвиток техніки, медицини та психології спонукав дослідників до відкриття та розробки нових наукових напрямків. Так Марі Габріель Ромен Вігуру розкрив феномен, відомий як шкірно-гальванічний рефлекс - мимовільна (рефлективна) зміна електричного опору шкіри в зв'язку з дією різних подразників (стимулів) або психічними переживаннями. Важливу роль в області дослідження шкірногальванічного рефлексу також зіграв відомий i впливовий американський психопатолог, психолог і психіатр початку 20 століття - Борис Сідіс, яким досліджено відношення емоцій і фізіологічних процесів до гальванометричних відхилень. Він довів, що спостережувані гальванометричні зміни були зумовлені фізіологі- 
чними процесами, які відображали розумовий стан, викликаний подразниками [6].

Італійський психіатр Чезаре Ломброзо застосував перший в історії прилад для детекції брехні - гідросфігмограф. Цей прилад реєстрував у обстежуваної людини зміни кров'яного тиску й частоти пульсу, після того, як їй ставилися запитання, релевантні до скоєного злочину. Італієць Вітторіо Бенуссі довів, що брехунів видає дихання. Частота й амплітуда дихання розцінювалися як інформативні показники, які реєструвалися за допомогою приладу - пневмографа. В. Бенуссі визначав правду й брехню, використовуючи т. 3. співвідношення тривалості вдиху і видиху [6].

Перший поліграф (детектор брехні), придатний для розслідування злочинів, був створений у 1921 році американцем Джоном Ларсоном, який розробив і застосував безперервний метод одночасної реєстрації змін частоти пульсу, кров'яного тиску й дихання. [6]

Найвидатнішим світовим поліграфологом є Ленерд Кілер, яким проведено понад 30000 поліграфологічних обстежень. Вченим модифіковано існуючі зразки поліграфів, застосовано поліграмний папір, психогальванометр (пристрій для вимірювання змін опору шкіри). Уведення каналу реєстрації шкірного опору значно підвищило точність результатів поліграфологічних обстежень. Ця версія поліграфа Кілера стала прототипом сучасного поліграфа, унаслідок чого Кілер уважається «батьком» сучасного поліграфа [6].
Найбільш грунтовно сформував проблему психологічних станів людини психолог М. Д. Левітов, який визначав психологічний стан, як особливу психологічну категорію: «це цілісна характеристика психічної діяльності за визначений період часу, яка виявляє своєрідність перебігу психічних процесів у залежності від відображуваних предметів і явищ дійсності, попереднього стану та властивостей особистості» [7].

А. В. Брушлінський розглядав зв'язки станів 3 процесами та особливостями психіки людини, зокрема, вченим обгрунтовано неділимість, нерозривність психологічних процесів та структур, їх проникливість одна в одну [1].

Психічний стан людини постійно змінюється, на нього впливають зовнішні та внутрішні подразники. В.А. Ганзен на основі проведеного аналізу визначив близько 63 понять та 187 термінів психологічних станів [3].

Класичну ж класифікацію психологічних станів провів М.Д. Левітов:

- $\quad$ особистісні та ситуативні стани;

- поверхневі та глибокі стани;

- $\quad$ стани позитивної та негативної дії;

- $\quad$ короткі та довготривалі стани;

- $\quad$ усвідомлені та неусвідомлені стани [7].

Психолог Леонард Сакс стверджував, що: «не існує психологічних рис обману. Немає жодних доказів, що параметри, які оцінює поліграф - серцебиття, тиск, виділення поту, дихання пов'язані з тим чи говорите Ви прав- 
ду, чи ні» [6].

Виклад основного матеріалу. Поліграф (або детектор брехні) психофізіологічний прилад, який функціонує, як комплексна багатоканальна апаратна методика реєстрації змін психофізіологічних реакцій людини у відповідь на подання певних психологічних стимулів. Аналіз інформації, яка надходить від людини-отримувача при застосуванні поліграфа, дає змогу здобувати орієнтувальну інформацію та виявляти ту, яку опитуваний приховує.

Технології поліграфологічних досліджень сьогодні стрімко розвиваються, в кожній окремо взятій країні мають свою специфіку та свій, так би мовити, шарм. Але без сумніву, в загальному вигляді людей цікавить формула: «Крадіжка, хабар, секс, зрада». А питання, які обробляються здебільшого формуються по таких координатах: Хто вкрав? Чи береш хабарі? Відкати? Чи зраджуєш? Звичайно, дослідник отримавши тему дослідження, ретельно її опрацьовує: готує тестову базу, вивчає нюанси справи, здійснює опитування (бесіду) досліджуваного, інструктує його по порядку проведення дослідження.

Сьогоднішній поліграфолог впроваджує одне з завдань психології - намагається вивчити психічне життя особистості через дослідження окремих моментів іiї конкретної діяльності. Відмінністю від практичного психолога у цьому розумінні $\epsilon$ те, що під час дослідження застосовується поліграф. Саме че- рез це ми вважаємо, що психологічна освіта повинна домінувати при підготовці спеціалістів-поліграфологів.

Окремими

спеціалістамиполіграфологами під час дослідження створюється атмосфера ізоляції для досліджуваного (відгороджують вікна шторами, замикають двері, звукоізолюють приміщення тощо). Звичайно, досліджуваний повинен не відволікатися на зайві звуки, відповідати на запитання, які йому транслюються дослідником, але, на наш погляд, занадто ізолізаційні умови для досліджуваного теж впливають на результат дослідження, досліджуваний повинен перебувати в звичайних умовах життєвого середовища.

Життя людини супроводжує цілий спектр психологічних станів. Для досягнення мети дослідження ми виділили психологічні характеристики особистості, які відображають статичні душевні переживання, тобто психологічні стани, які відчуває особистість під час проведення полі графологічних досліджень це брехня, омана, настрій, радість, тривога, страх, хвилювання, спокій.

Брехня - психологічна категорія, свідома передача інформації про неіснуючу дійсність. Мета брехуна - дезінформувати дослідника, ввести його в оману відносно дійсного стану справ у тій чи іншій сфері досліджуваної дійсності. Для розуміння природи брехні слід визначитись 3 істинним станом справ ділянки дослідження, цільовою поведінкою 
суб'єкта дослідження. 3 позиції поліграфологічного дослідження брехливими є не лише повідомлення, які викривляють на свій усвідомлений розсуд факти, а й ті якими маніпулюють. Через наявність метафор, іроній, юмору поліграфологи дійшли висновку, що досліджуваний повинен давати стверджувальну відповідь, як правило однослівну: так-ні.

Проведені психологічні дослідження вказують на те, що частіше брешуть досліджувані $з$ підвищеною тривожністю, малою стійкістю до стресу, при цьому зв'язок між інтелектом та брехнею не виявлений[5].

Брехня це слова. Досліджувані, які брешуть починають підбирати потрібні слова, в контекст розмови конструктивом вводять непотрібні слова, не задумуються над відповідями, затягують розмову, відповідь.

Слід врахувати, що брехня може мати своє виправдання, звичайно 3 моральних принципів. Скажімо, для нас, брехню військовополоненого можна вважати брехнею, а для його співвітчизників, та для нього самого це не брехня, а геройський вчинок.

Відомий постулат: «більшість людей готові поступити не чесно через свою вигоду» актуальний і досі. I його теж необхідно враховувати досліднику.

Масова свідомість сприймає сучасну брехню, як явище необхідне для існування в життєвому середовищі. Ми ж привертаємо увагу на окрему форму брехні, більш небезпечну, це омана.
Омана - це вже психологічний вчинок, твердження про наявну, на переконання досліджуваного, істину в питаннях дослідження. Тобто це не брехня, а напівправда. Розрахунок такого досліджуваного простий - дослідник зробить не вірні висновки, які влаштовують досліджуваного. У цьому процесі досліджуваний сповіщає про окремі правдиві, дійсні факти, а окремі факти приховує, таким чином, весь предмет дослідження дослідник не прослідковує.

Метою омани є направлення мислення про предмет дослідження по шляху актуалізації ситуацій, які частіше за інших зустрічаються. Омана базується на неповноті інформації [4].

Омана, на відміну від брехні, явище природне. В живій природі обман допомагає представникам тваринного світу вижити, захиститись від хижаків.

Отже, наявна різниця між брехнею та обманом: брехня направлена на видозміни референтного компонента знань дослідника про наявну ситуацію дослідження, а обман направлений на зміни суб'єктності світосприйняття дослідником. В обманному повідомленні істина викривлена через появу у свідомості дослідника помилкових висновків 3 наявної правдивої інформації.

Настрій - психічний стан, який характеризує емоційний фон психічного життя особистості. Він може бути радісним, сумним, тривожним, бадьорим. 
Формування настрою здійснюється або поступово, або раптово (при виникненні радісної події, ситуації). Він залежний від здоров'я особистості, іiі суспільного становища, професійної діяльності. Настрій може змінюватись і від думки, дії чи бездіяльності, спогаду. Для такої зміни потрібне підготовлене підгрунтя, в якому враження, яке виникло узагальнилося б [2].

Настрій впливає на виникнення негативних психологічних станів особистості до або під час проведення психофізіологічних досліджень.

Страх - реакція особистості на наявну чи уявну небезпеку. Страх спонукає розвитку таких психічних станів, як нервування, переживання, неадекватність поведінки, переляк. Страх негативно впливає на пам'ять, сприймання, мислення, увагу, почуття, волю. Структурно цей психологічний стан складається 3 сприйняття, оцінки уявної в цей момент або реальної загрози, при такому стані відбуваються зміни психіки, як правило в негативну сторону, які дестабілізують уся подальші психологічні стани особистості.

Тривога - психологічний стан, при якому ймовірно затримуються неприємні ситуації в реальний усвідомлений, в окремих ситуаціях, небезпечний момент життєдіяльності людини. Тривозі притаманні стурбованість, побоюваність. Тривога межує зі страхом. Наявність в психічній поведінці особистості тривоги свідчить про недостатню прис- тосованість до навколишньої дійсності, недолугість реакції на іï зміну.

Хвилювання - підвищене збудження, напруження і страх, пов'язаний з негативними передчуттями людини. Хвилювання є показником загального стану людини. Втрата хвилювання робить людину байдужою до співпереживання, надмірне ж хвилювання спричиняють неврівноваженість, збудженість, не володіння собою. Хвилювання, як і страх виникають, коли нервові центри не можуть дати адекватну реальному факту відповідь на запитання. Психолог О. Кондаш вважав, що хвилювання - негативне передчуття суб'єктом наслідків своєї діяльності у тій чи іншій ситуації [6].

Радість - позитивний психологічний стан особистості, підвищена емоція після якоїсь дії, що задовольнила сформовану потребу у чому-небудь очікуваному. Радості притаманне почуття піднесеності, задоволеності зробленою роботою, отриманим повідомленням про що-небудь. Впевненість, яка виникає після радості спонукає особистість вирішувати складні, не вирішенні проблемні питання. Радість залежна від інших людей, подій, обстановки, ситуацій та інших чинників. При цьому подолання перешкод в досягненні життєвих цілей, стратегій $є$ тими чинниками, які спонукають особистість відчувати короткотермінову радість, радість виникає і при позитивній взаємодії з іншими особистостями, іiі не можливо запланувати. 
Спокій - психологічний стан рівноваги почуттів, емоцій, дій. Спокій мінливий, залежний від численних психологічних подразників. Як правило, особистість задіяна в прикордонній діяльності набуває короткочасного стану спокою [2].

Вміло вибудувана досліджуваним стратегія поведінки під час організації (попередньої бесіди), проведенні процедури психофізіологічних досліджень гарантує особистості психологічний стан спокою.

Уміння спеціаліста-поліграфолога вивчити психологічний стан досліджуваного $€$ обов'язковою, на наше переконання, умовою ефективного поліграфологічного дослідження. Звичайно, наявність психологічних знань у дослідника $є$ важливим фактором досягнення ефективного кінцевого результату. Досвідчений поліграфолог здатен ще до початку проведення дослідження скласти психологічний образ досліджуваного, в окремих випадках він може спрогнозувати, які наміри має досліджуваний при проведенні тестування, чи налаштований тестувальник на брехню, оману, його психологічний стан спокою, рівноваги, яка його самодисципліна тощо.

Неоднозначність доказів здобутих поліграфологічним дослідженням змушує нас рекомендувати застосовувати комбінований спосіб отримання правдивої інформації. I у цьому сенсі важливим є професійна підготовка спеціаліста-поліграфолога. Він повинен мати знання 3 філософії, психології, права, анатомії, математики, фізики. Вміло поєднуючи сучасні психофізіологічні технології з своїми знаннями, спеціаліст здобуде ймовірісно високий результат дослідження, у тому числі й через те, що суспільна думка про викриття брехні, омани поліграфом впливає на досліджуваного ще до початку самого дослідження. Людина переконана, що поліграф здатен розкрити іii неправдиві відомості. В таким умовах спостереження за особистістю досліджуваного дають можливість бачити повну картину ситуації. Покладатися лише на результати психофізіологічних досліджень поліграфологу не потрібно. Важливо перед початком дослідження встановити, чи має досліджуваний образу на те, що йому не довіряють, рекомендували йому пройти випробування на детекторі. В таких випадках особистість, 3 наявною образою, буде захищатись, доводити свою правоту, свою невинуватість. Людина, яка говорить правду дає стверджувальні відповіді, може висловлювати свої зорові, смакові, слухові, інтуїтивні почуття. Така тактика підтверджується результатами психологічних досліджень.

Подальшими напрямами досліджень можуть бути розробки системи поглядів психології особистості на проблеми прогнозування недостатньої чесності через припущення майбутньої делінквентної поведінки через показники особистісної девіантності, як соціапатична особистість та психопатична девіація. 


\section{Перелік використаних джерел:}

1. Брушлинский А. В. Проблема субъекта в психологической науке/А.В. Брушлинский // Психол. журн. 1991. - T. 12. - № 6. - C. 3-11.

2. Вилюнас В. К. Психология эмоциональных явлений /

В.К.Вилюнас. - М.: Изд-во МГУ, 1976.-143 с.

3. Ганзен В. А. Систематизация психических состояний / В. А. Ганзен // Психология состояний: хрестоматия / сост. Т. Н. Васильева, Г. Ш. Габдреева, А. О. Прохоров / под. ред. А. О. Прохорова. - СПб.: Речь, 2004. C. 60-64.

4. Гусейнов Г. Ложь как состояние сознания // Вопр.философ. 1989. №11. С.64-76.

5.Знаков В.В. Понимание субъектом правды о моральном проступке другого человека: нормативная этика и психология нравственного сознания \\ Психол. журнал. 1993. T.14.№1.C.32-43.

6. Історія поліграфа (детектора брехні) [Електронний pecypc]. - Режим доступу :

http://polygraph-west.com.ua/history_ua.php.

7. Левитов Н. Д. О психологических состояниях человека. - М., Просвещение, 1964. - 344c.

8. Конституція України. - К. : Паливода А. В., 2005. $104 \mathrm{c}$.

9. Максименко С. Д. Розвиток психіки в онтогенезі : в 2

т. / С. Д. Максименко. - К. : Форум, 2002. Т. 1:Теоретико-методологічні проблеми генетичної психології -319 с.

10. Маслоу А. Мотивация и личность/пер. с анг.-3-е изд. -Спб.: Питер.,2003.-392 с.

11. Mosso A. Angelo Mosso's Circulation of blood in the human brain / ed., with commentary, by M. E. Raichle, G. M. Shepherd. - New York: Oxford Univ. Press 2014. XXXII $202 \mathrm{c}$.

\section{References (Transliteration):}

1. Brushlynskyy A. V. Problema subъekta v psykholohycheskoy nauke/A.V. Brushlynskyy // Psykhol. zhurn. - 1991. - T. 12. - \# 6. - S. 3-11.

2. Vylyunas $V . \quad K$. Psykholohyya эmotsyonal'nukh yavlenyy / V.K.Vylyunas. - M.: Yzd-vo MHU, 1976.-143 s. 3. Hanzen $V$. A. Systematyzatsyya psykhycheskykh sostoyanyy / V. A. Hanzen // Psykholohyya sostoyanyy: khrestomatyya / sost. T. N. Vasyl'eva, H. Sh. Habdreeva, A. O. Prokhorov / pod. red. A. O. Prokhorova. - SPb.: Rech', 2004. - S. 60-64.

4. Huseynov H. Lozh' kak sostoyanye soznanyya // Vopr.fylosof. 1989. \#11. S.64-76.

5. Znakov V. V. Ponymanye subъektom pravdы o moral'nom prostupke druhoho cheloveka: normatyvnaya эtyka y psykholohyya nravstvennoho soznanyya \ Psykhol. zhurnal. 1993. T.14.\#1.S.32-43.

6. Istoriya polihrafa (detektora brekhni) [Elektronnyy resurs]. - Rezhym dostupu : http://polygraph-west.com.ua/ history_ua.php.

7. Levytov N. D. O psykholohycheskykh sostoyanyyakh cheloveka. - M., Prosveshchenye, 1964. - 344s.

8. Konstytutsiya Ukrayiny. - K. : Palyvoda A. V., 2005. $104 \mathrm{~s}$.

9. Maksymenko S. D. Rozvytok psykhiky v ontohenezi : v 2

t. / S. D. Maksymenko. - K. : Forum, 2002.T.1:Teoretykometodolohichni problemy henetychnoyi psykholohiyi -319 s.

10. Maslou A. Motyvatsyya y lychnost'/per. s anh.-3-e yzd.Spb.: Pyter.,2003.-392 s.

11. Mosso A. Angelo Mosso's Circulation of blood in the human brain / ed., with commentary, by M. E. Raichle, G. M. Shepherd. - New York: Oxford Univ. Press 2014. XXXII $202 \mathrm{c}$. 


\section{Mul Serhii}

Doctor in psychology, associate professor of National Pedagogical University named after M. P. Drahomanova, Kyiv (Ukraine)

\section{PROBLEMS OF USING POLIGRAPHIC RESEARCHES}

\section{ABSTRACT}

The article examines the problem of ambiguity in the use of the polygraph, examples of the introduction of polygraphs are given. The author distinguishes an individual static emotional experience that is the psychological states that personality experiences during polygraph examinations such as lies, deceit, mood, joy, anxiety, fear, excitement, calm. It is emphasized on the presence of the necessary condition - the ability of a polygraph specialist to penetrate the psychological state of the subject. Attention is drawn to the fact that an experienced polygraph examiner is able to compose the psychological image of the subject before the study, because of the contradiction in the views on the evidence base obtained by polygraph examinations, the author recommends using a combined method of obtaining true information. The attention is paid to the training of a polygraph specialist. He must have knowledge of philosophy, psychology, law, anatomy, mathematics and physics. Attention is drawn to the conditions created by polygraph specialists during the study, it is noted that the atmosphere of isolation for the subject is undesirable. The author agrees with separate statements about the fact that the subject should not be distracted by superfluous sounds, to answer the questions that are transmitted by the researcher, but is convinced that too hermetic conditions affect the result of the study, it is recommended to create normal living environment conditions. The further prospect of research in creating a system of psychological views on the problems of predicting lack of honesty through the assumption of future delinquent behavior through the indicators of personal deviance, as a sociopathic personality and psychopathic deviation is seen.

Key words: polygraph, psychophysiological research, psychological state, detector, research, tests, evaluation, conclusions, values, choice.

\section{Мул Сергей Анатолиевич}

Доктор психологических наук, доцент Национального педагогического университета имени Н. П. Драгоманова, г. Киев (Украина)

\section{ПРОБЛЕМЫ ИСПОЛЬЗОВАНИЯ ПОЛИГРАФОЛОГИЧЕСКИХ ИСЛЕДОВАНИЙ}

Аннотация. В статье исследуется проблема неоднозначности использования полиграфа, приводятся примеры использования полиграфов. Автором выделяются отдельные статистические душевные переживания, или психологические состояния, которые чувствует личность при проведении полиграфологических исследований такие как ложь, обман, настроение, радость, тревога, страх, пережи- 
вание, спокойствие. Отмечается наличие необходимого условия - умении специалиста полиграфолога изучить психологическое состояние испытуемого. Обращается внимание на то, что опытный полиграфолог способен еще до начала проведения исследования составить психологический образ испытуемого, из-за противоречий взглядов на доказательную базу добытую полиграфологическим исследованием автор рекомендует использовать комбинированный способ получения правдивой информации. Выделяется подготовка специалиста-полиграфолога. Он должен иметь знания философии, психологии, права, анатомии, математики, физики. Просматривается дальнейшая перспектива исследований создания системы взглядов психологии на проблемы прогнозирования недостаточной чесности через предположения будующей делинквентного поведения через показатели личносной девиантности, как социапатичной личности и психопатической девиации.

Ключевые слова: полиграф, психофизиологическое исследование, психологическое состояние, детектор, исследование, тесты, оценка, выводы, ценности, выбор. 